\title{
Optimization of Positive End-Expiratory Pressure by Volumetric Capnography Variables in Lavage-Induced Acute Lung Injury
}

\author{
Yi Yang ${ }^{a}$ Yingzi Huang ${ }^{a}$ Rui Tang ${ }^{b}$ Qiuhua Chen ${ }^{a}$ Xia Hui ${ }^{a}$ Yang Li ${ }^{a}$ \\ Qing $\mathrm{Yu}^{\mathrm{a}}$ Hongjie Zhao ${ }^{\mathrm{a}}$ Haibo Qiu $^{\mathrm{a}}$ \\ Departments of Critical Care Medicine, ${ }^{a}$ Zhong-Da Hospital, Southeast University School of Medicine, Nanjing, and \\ ${ }^{b}$ First Affiliated Hospital of Anhui Medical University, Hefei, PR China
}

\section{Key Words}

Acute respiratory distress syndrome - End-expiratory

lung volume . Positive end-expiratory pressure .

Volumetric capnography

\begin{abstract}
Background: In the acute respiratory distress syndrome (ARDS), lung-protective ventilation strategies combine the delivery of small tidal volumes (VT) with sufficient positive end-expiratory pressure (PEEP). However, an optimal approach guiding the setting of PEEP has not been defined. Monitoring volumetric capnography is useful to detect changes in lung aeration. Objectives: The aim of this study was to determine whether volumetric capnography may be a useful method to determine the optimal PEEP in ARDS. Methods: In 8 lung-lavaged piglets, PEEP was reduced from 20 to $4 \mathrm{~cm} \mathrm{H} \mathrm{H}_{2} \mathrm{O}$ in steps of $4 \mathrm{~cm} \mathrm{H}_{2} \mathrm{O}$ every 10 min followed by full lung recruitment. Volumetric capnography, respiratory mechanics, blood gas analysis, hemodynamic data and whole-lung computed tomography scans were obtained at each PEEP level. Results: After lung recruitment, end-expiratory lung volume progressively decreased from 1,160 \pm 273 $\mathrm{ml}$ at PEEP $20 \mathrm{~cm} \mathrm{H}_{2} \mathrm{O}$ to $314 \pm 86 \mathrm{ml}$ at PEEP $4 \mathrm{~cm} \mathrm{H}_{2} \mathrm{O}$. The ratio of alveolar dead space $\left(\mathrm{V}_{\text {alv }}\right)$ to alveolar $\mathrm{VT}\left(\mathrm{VT}_{\text {alv }}\right)$ and the phase III slope of volumetric capnography $\left(\mathrm{S}_{\text {III }}\right)$ reached
\end{abstract}

a minimum at PEEP $16 \mathrm{~cm} \mathrm{H}_{2} \mathrm{O}$. At this PEEP level, overaerated lung regions were significantly reduced, nonaerated lung regions did not increase, and partial pressure of oxygen in arterial blood/fraction of inspired oxygen (P/F) and static respiratory system compliance ( $\mathrm{Crs}$ ) reached a maximum. At PEEP levels $<16 \mathrm{~cm} \mathrm{H}_{2} \mathrm{O}$, nonaerated lung regions significantly increased, $\mathrm{P} / \mathrm{F}$ and $\mathrm{Crs}$ deteriorated, and $\mathrm{VD}_{\text {alv }} / \mathrm{VT}_{\mathrm{alv}}$ and $S_{|| I}$ began to increase. Conclusions: In this surfactantdepleted model, PEEP at the lowest $\mathrm{VD}_{\text {alv }} / \mathrm{VT}_{\text {alv }}$ and $\mathrm{S}_{\text {|II }}$ allows an optimal balance between lung overinflation and collapse. Hence, volumetric capnography is a useful bedside approach to identify the optimal PEEP.

(c) 2013 S. Karger AG, Basel

\section{Introduction}

It is well recognized that lung-protective ventilation strategies, including low tidal volume $(\mathrm{VT})$, recruitment maneuvers (RM) and sufficient positive end-expiratory pressure (PEEP), should be applied for the management of patients with the acute respiratory distress syndrome (ARDS) $[1,2]$. Currently, the major difficulty in applying

Y. Yang and Y. Huang should be considered as co-first authors.

\section{KARGER}

E-Mail karger@karger.com

www.karger.com/res
(C) 2013 S. Karger AG, Basel

0025-7931/13/0871-0075\$38.00/0
Haibo Qiu

Department of Critical Care Medicine, Zhong-Da Hospital

Southeast University School of Medicine

Nanjing 210009 (PR China)

E-Mail haiboq2000@gmail.com 
this strategy is determining the optimal PEEP to prevent end-expiratory lung collapse and alveolar overinflation, the two major culprits in ventilator-induced lung injury $[3,4]$. Despite the introduction of many methods to determine PEEP in ARDS, the optimal approach remains undefined.

Volumetric capnography has the potential to aid in titrating the optimal PEEP in ARDS. Increased dead space ventilation is a characteristic of ARDS and a powerful predictor of mortality in ARDS patients $[5,6]$. Lung recruitment may decrease the phase III slope of the capnogram $\left(\mathrm{S}_{\mathrm{III}}\right)$, increase the slope of phase II $\left(\mathrm{S}_{\mathrm{II}}\right)$ and limit the alveolar dead space $\left(\operatorname{VD}_{\text {alv }}\right)[7,8]$. On the other hand, alveolar overinflation induced by high PEEP may induce an increase in $\mathrm{VD}_{\mathrm{alv}}$ [9-11]. Hence, evidence supports the value of monitoring the dead space fraction in titrating PEEP in ARDS $[12,13]$.

Considering the above concepts, we hypothesized that volumetric capnography may be a valuable bedside method to determine the optimal PEEP in ARDS. Therefore, the aim of this study was to determine which of the standard volumetric capnography variables best identify the optimal PEEP during a decremental PEEP trial after full lung recruitment.

\section{Materials and Methods}

\section{Study Design}

Eight piglets ( 2 male and 6 female) weighing $33.8 \pm 2.2 \mathrm{~kg}$ were premedicated with intramuscular midazolam $(0.3 \mathrm{mg} / \mathrm{kg})$ and ketamine $(10 \mathrm{mg} / \mathrm{kg})$. Animals were subsequently anesthetized by a continuous infusion of pentobarbital (10-20 mg/kg/h), fentanyl $(3-6 \mu \mathrm{g} / \mathrm{kg} / \mathrm{h})$ and pancuronium $(0.5 \mathrm{mg} / \mathrm{kg} / \mathrm{h})$. A continuous infusion of normal saline was delivered at a rate of $5 \mathrm{ml} / \mathrm{kg} / \mathrm{h}$ i.v. Body temperature (rectal) was maintained at $36-38^{\circ} \mathrm{C}$ with an electric blanket.

Animals were tracheostomized and mechanically ventilated in the supine position through an endotracheal tube (internal diameter: $8 \mathrm{~mm}$; Mallinckrodt, Athlone, Ireland) using a constant-flow, volume-controlled mode (Engström CareStation, Datex, General Electric, Helsinki, Finland). At baseline, the animals were ventilated with a tidal volume $(\mathrm{VT}) 10 \mathrm{ml} / \mathrm{kg}$, respiratory rate (RR) 20 breaths/min, $\mathrm{PEEP} 0 \mathrm{~cm} \mathrm{H}_{2} \mathrm{O}$, an inspiratory/expiratory ratio (I:E) of $1: 2$ and a fraction of inspired oxygen $\left(\mathrm{FiO}_{2}\right)$ of 0.5 .

After completing the animal preparation, an RM was performed in pressure control mode with PEEP of $20 \mathrm{~cm} \mathrm{H}_{2} \mathrm{O}$, peak inspiratory pressure $40 \mathrm{~cm} \mathrm{H}_{2} \mathrm{O}, \mathrm{RR} 20$ breaths/min, I:E of $1: 1$ and $\mathrm{FiO}_{2}$ of 0.5 for $2 \mathrm{~min}$ in order to restore the lung volume history. After a 30-min period of mechanical ventilation, measurements were obtained at PEEP $0 \mathrm{~cm} \mathrm{H}_{2} \mathrm{O}$ (baseline).

Lung injury was induced by repetitive lung lavage with warm saline $\left(30 \mathrm{ml} / \mathrm{kg}\right.$ at $\left.37-39^{\circ} \mathrm{C}\right)$ until the partial pressure of oxygen in arterial blood $\left(\mathrm{PaO}_{2}\right)$ was below $150 \mathrm{~mm} \mathrm{Hg}$ at pure oxygen and a PEEP of $0 \mathrm{~cm} \mathrm{H}_{2} \mathrm{O}$ and stabilized for $60 \mathrm{~min}$.

After stabilizing the lung injury, the animals were transferred to the CT scan room, and another set of parameters was obtained at PEEP $0 \mathrm{~cm} \mathrm{H}_{2} \mathrm{O}$ (ARDS). Next, another RM was performed in pressure control mode with PEEP $20 \mathrm{~cm} \mathrm{H}_{2} \mathrm{O}$, peak inspiratory pressure $50 \mathrm{~cm} \mathrm{H}_{2} \mathrm{O}$, RR 20 breaths/min, I:E 1:1 and $\mathrm{FiO}_{2} 1.0$ for $2 \mathrm{~min}$. Thereafter, the ventilator was switched to $\mathrm{VT} 6 \mathrm{ml} / \mathrm{kg}, \mathrm{RR}$ 30 breaths/min, I:E 1:2, $\mathrm{FiO}_{2} 1.0$ and PEEP $20 \mathrm{~cm} \mathrm{H}_{2} \mathrm{O}$. Two minutes later, an arterial blood gas analysis was obtained to determine the degree of lung recruitment after which $\mathrm{FiO}_{2}$ was adjusted to 0.5. A decremental PEEP trial in steps of $4 \mathrm{~cm} \mathrm{H}_{2} \mathrm{O}$ starting at 20 $\mathrm{cm} \mathrm{H}_{2} \mathrm{O}$ down to $4 \mathrm{~cm} \mathrm{H}_{2} \mathrm{O}$ was instituted. Each level of PEEP was maintained for $10 \mathrm{~min}$ before data acquisition. At the end of the study, all experimental animals were euthanized by an overdose of potassium chloride.

Animals were excluded from the study if they had a $\mathrm{PaO}_{2} / \mathrm{FiO}_{2}$ ratio $(\mathrm{P} / \mathrm{F})<450 \mathrm{~mm} \mathrm{Hg}$ at baseline or if lung recruitment was considered incomplete at PEEP $20 \mathrm{~cm} \mathrm{H}_{2} \mathrm{O}$ (defined as $\mathrm{PaO}_{2}+\mathrm{PaCO}_{2}$ $<400 \mathrm{~mm} \mathrm{Hg}$ at $\mathrm{FiO}_{2}$ of 1.0 [14]).

\section{Methods}

The study was conducted at the Southeast University Medical School after approval by the institutional animal ethics committee.

Hemodynamic Monitoring and Blood Gas Measurements

Central venous and pulmonary artery pressures were measured using a 7.5-french pulmonary artery catheter (Arrow, Reading, Pa., USA) advanced through the right internal jugular vein. The right femoral artery was cannulated with a 4 -french, $8-\mathrm{cm}$ PiCCO catheter (Pulsion Medical Systems, Feldkirchen, Germany). Hemodynamic monitoring was conducted using PM-9000 Express (Mindray, Shenzhen, China) and PiCCO plus (Pulsion Medical Systems). For blood pressure measurements, calibrated pressure transducers (PV8115; Pulsion Medical Systems) referenced to atmospheric pressure at the mid-thorax level were used. Arterial and mixed venous blood gases were analyzed using a blood gas analyzer (Critical Care Xpress, Nova Biomedical, Waltham, Mass., USA). Venous admixture was calculated using the formula (capillary oxygen content - arterial oxygen content)/(capillary oxygen content - mixed venous oxygen content).

\section{Respiratory Mechanics and Volumetric Capnography}

Variables

Respiratory mechanics and carbon dioxide measurements were performed with a Ventrak 1550/Capnogard 1265 (Novametrix, Wallinford, Conn., USA). Volumetric capnography was recorded and analyzed using Aplus software (Novametrix). End-expiratory lung volume (EELV) was determined twice by the nitrogen washin/washout method integrated in the ventilator, which is an automated procedure with an $\mathrm{FiO}_{2}$ step change of 0.1 as previously described by Olegård [15].

Airway opening pressure and flow were measured by a fixedorifice, differential pressure flow sensor (model 7222; Novametrix; dead space $8 \mathrm{ml}$ ). $\mathrm{CO}_{2}$ measurement was performed by an infrared mainstream sensor (Capnostat; Novametrix), response time $<75 \mathrm{~ms}$, accuracy $\pm 5 \%$ at values between 41 and $100 \mathrm{~mm}$ $\mathrm{Hg}$, and $\pm 2 \mathrm{~mm} \mathrm{Hg}$ for values $<40 \mathrm{~mm} \mathrm{Hg}$ with a resolution $1 \mathrm{~mm} \mathrm{Hg}$ (dead space of airway adapter $5 \mathrm{ml}$ ). EELV was measured by a Pedi-lite flow sensor (accuracy $6 \%$ or $4 \mathrm{ml}$, dead space 


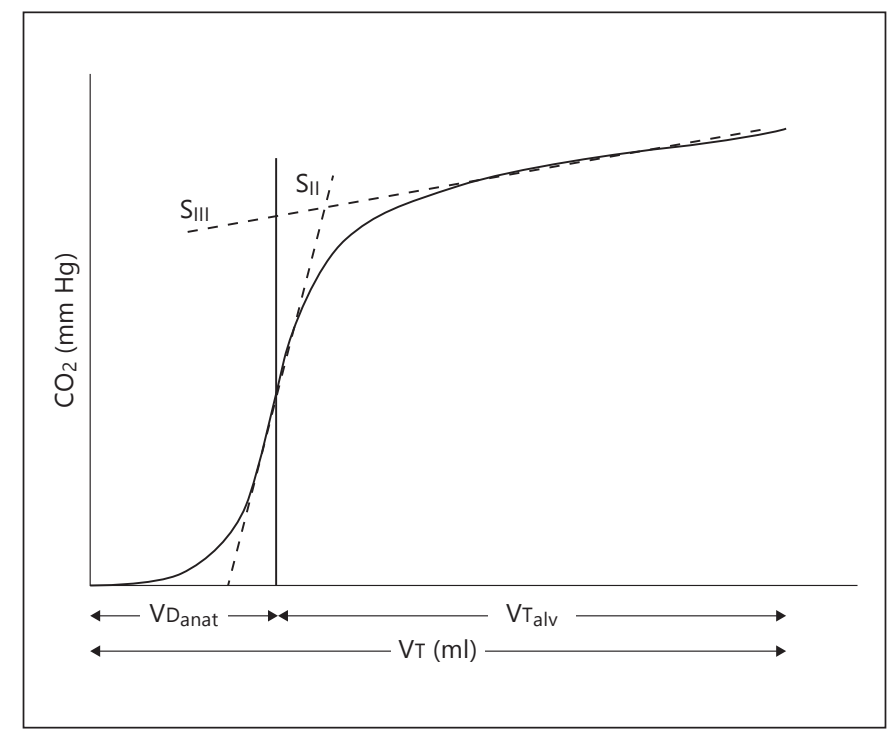

Fig. 1. Volumetric capnography curve and its derived variables. $\mathrm{VD}_{\text {anat }}$ was determined by the Fowler method. $\mathrm{S}_{\text {II }}$ was calculated from the data points between the start of phase II and $40 \%$ of the capnogram. $\mathrm{S}_{\text {III }}$ was calculated from data points between 40 and $80 \%$ of the capnogram.

$2.5 \mathrm{ml}$ ). All sensors were placed at the airway opening. Sensor calibration was performed according to the manufacturer's guidelines.

At the end of each protocol step, three 3-second end-inspiratory and end-expiratory hold maneuvers were performed to calculate the static respiratory system compliance (Crs). Physiologic dead space $\left(\mathrm{VD}_{\mathrm{phy}}\right)$ was calculated using the Enghoff modification of the Bohr formula. Anatomical dead space $\left(\mathrm{VD}_{\text {anat }}\right)$ was determined by the Fowler method. Alveolar dead space $\left(V D_{\text {alv }}\right)$ was computed by subtracting $\mathrm{VD}_{\text {anat }}$ from $\mathrm{VD}_{\text {phy }}$. The ratio of $\mathrm{VD}_{\text {alv }}$ to alveolar tidal volume $\left(\mathrm{VT}_{\mathrm{alv}}\right)$ was obtained by dividing $\mathrm{VD}_{\mathrm{alv}}$ by $\mathrm{VT}_{\mathrm{alv}}\left(\mathrm{VT}_{\mathrm{alv}}=\mathrm{VT}-\mathrm{VD}_{\mathrm{anat}}\right)$. The maximum $\mathrm{S}_{\mathrm{II}}$ of the capnogram was calculated, using a linear regression from the data points from the start of phase II and $40 \%$ of the expired volume. $\mathrm{S}_{\text {III }}$ was calculated using a linear regression, considering all data points between 40 and $80 \%$ of the capnogram. A mean value for $\mathrm{S}_{\mathrm{II}}$ and $\mathrm{S}_{\text {III }}$ was calculated from 10 breaths. Figure 1 shows a volumetric capnography curve and its derived variables used in our study.

Thoracic Computed Tomography Scan and Lung Morphology Analysis

At each PEEP level, whole-lung computed tomography (CT) scans were performed during end-expiratory breath holding (Somatom Sensation 64; Siemens, Forchheim, Germany), using a $512 \times 512$ matrix, $120 \mathrm{kV}, 120 \mathrm{mAs}$, an exposure time of $0.33 \mathrm{~s} /$ rotation, a pitch of 1.2 and a collimation of $0.6 \mathrm{~mm}$. The images were reconstructed with 5-mm slice thickness using a body reconstruction filter (Siemens notation, B80f). The voxel volume ranged from $0.44 \times 0.44 \times 5$ to $0.60 \times 0.60 \times 5 \mathrm{~mm}\left(0.97-1.8 \mathrm{~mm}^{3}\right)$. The CT number characterizing each voxel was expressed in Hounsfield units $(\mathrm{Hu})$.

Titration of PEEP by Volumetric Capnography
To analyze the CT images, a commercially available software was used (Pulmo Option, Syngo; Siemens). All of the images were assessed at a window width of $1,600 \mathrm{Hu}$ and a window center of $-600 \mathrm{Hu}$. The lung parenchyma was selected as region of interest by excluding the chest wall, mediastinum, large vessels and airways by manual segmentation. The voxels of each CT slice were distributed into 10 compartments ranging from $-1,000$ to $+100 \mathrm{Hu}$ with an interval of $100 \mathrm{Hu}$. For each compartment of a known number of voxels, lung, gas and tissue volumes were calculated as follows [16]: lung volume $=$ [number of voxels $\times$ volume of the voxel]; gas volume $=[($ mean $\mathrm{CT} /-1,000) \times$ lung volume (volume of gas $=0$ if the compartment considered had a CT number above 0)]; tissue volume = [lung volume - gas volume]. The total volume of lung, gas (EELV - CT) and tissue was computed by summing the value of each volume of all slices. Different aerated lung regions were divided into four functional compartments according to the standard definition based on $\mathrm{Hu}$ [17]: nonaerated $(+100$ to $-100 \mathrm{Hu})$, poorly aerated $(-100$ to -500 $\mathrm{Hu})$, normally aerated $(-500$ to $-900 \mathrm{Hu})$ and hyperinflated $(-900$ to $-1,000 \mathrm{Hu})$.

\section{Statistical Analysis}

Data are presented as means \pm SD unless specified otherwise. Statistical comparisons of the data over time were conducted using repeated-measure ANOVA followed by least significant difference for multiple comparisons. A linear regression analysis was performed to evaluate the relationship between EELV, volumetric capnography variables, lung morphology and venous admixture. $\mathrm{p}<0.05$ was considered to be statistically significant. A statistics software package was used for the analyses (SPSS 16.0; SPSS, Chicago, Ill., USA).

\section{Results}

The study was conducted from December 2011 to August 2012.

After stabilizing the ARDS model, the EELV, P/F and Crs decreased significantly while venous admixture and $\mathrm{PaCO}_{2}$ increased significantly. All capnography variables, except $\mathrm{VD}_{\text {anat }} / \mathrm{VT}$, were significantly different from the baseline measurements.

During the PEEP titration phase, EELV was progressively reduced from $1,160 \pm 273 \mathrm{ml}$ at PEEP $20 \mathrm{~cm} \mathrm{H}_{2} \mathrm{O}$ to $314 \pm 86 \mathrm{ml}$ at PEEP $4 \mathrm{~cm} \mathrm{H}_{2} \mathrm{O}$, while $\mathrm{P} / \mathrm{F}$ and Crs began to decline at a PEEP of $12 \mathrm{~cm} \mathrm{H}_{2} \mathrm{O}$ (fig. 2). During the same process, nonaerated lung volume $(\mathrm{CT})$ increased significantly at all PEEP levels $<16 \mathrm{~cm} \mathrm{H}_{2} \mathrm{O}$. A reduction in PEEP gradually decreased the amount of overly and normally aerated lung volume (fig. 3).

During the decremental PEEP trial, $\mathrm{VD}_{\mathrm{phy}} / \mathrm{VT}$ and $\mathrm{VD}_{\mathrm{alv}} / \mathrm{VT}_{\text {alv }}$ showed similar patterns of change. However, $\mathrm{VD}_{\text {phy }} / \mathrm{VT}$ reached the minimum at a PEEP of $8 \mathrm{~cm} \mathrm{H}_{2} \mathrm{O}$ whereas the lowest $\mathrm{VD}_{\text {alv }} / \mathrm{VT}_{\text {alv }}$ was at a PEEP of $16 \mathrm{~cm}$ $\mathrm{H}_{2} \mathrm{O} . \mathrm{VD}_{\text {anat }} / \mathrm{VT}$ decreased with each reduction in PEEP. 
Fig. 2. Changes in $\mathrm{PaO}_{2} / \mathrm{FiO}_{2}$, venous admixture, EELV and static compliance at the baseline, ARDS model and during the decremental PEEP trial. * $\mathrm{p}<0.05$ vs. ARDS; ** $\mathrm{p}<0.05$ vs. PEEP20 (PEEP $20 \mathrm{~cm} \mathrm{H}_{2} \mathrm{O}$ ). Data are expressed as means \pm SD.

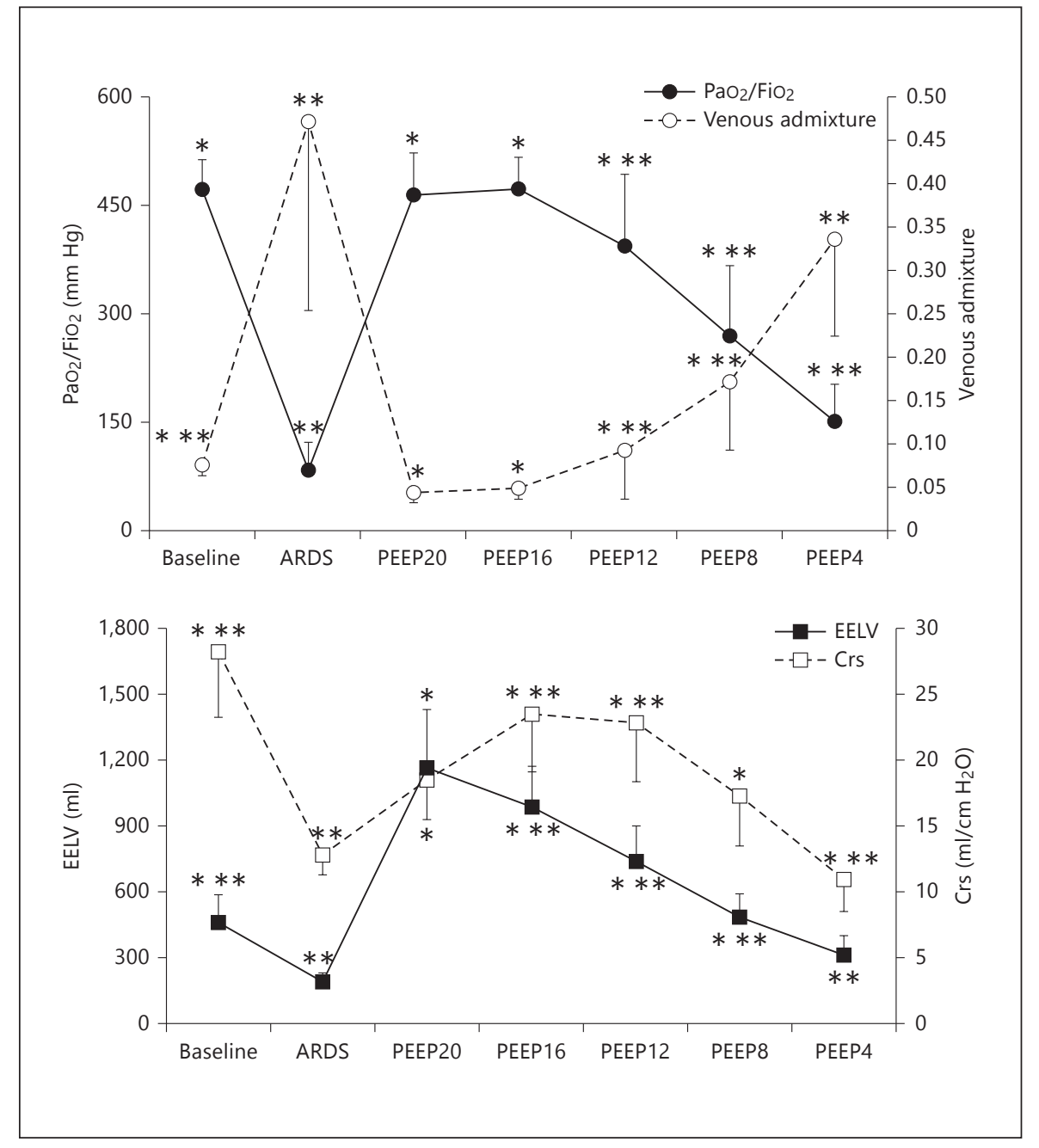

Moreover, $\mathrm{S}_{\text {III }}$ decreased significantly and reached a minimum at PEEP $16 \mathrm{~cm} \mathrm{H}_{2} \mathrm{O}$ whereas $\mathrm{S}_{\mathrm{II}}$ improved at a PEEP of 16 and $12 \mathrm{~cm} \mathrm{H}_{2} \mathrm{O}$; this change did not reach significance (fig. 4).

EELV was significantly correlated to normally aerated $(\mathrm{r}=0.918)$, nonaerated $(\mathrm{r}=-0.715)$, and overly aerated lung volume $(\mathrm{r}=0.592) . \mathrm{VD}_{\mathrm{alv}} / \mathrm{VT}_{\mathrm{alv}}$ was highly correlated to nonaerated $(\mathrm{r}=0.681)$ and normally aerated lung volumes $(\mathrm{r}=-0.512)$ as well as venous admixture $(\mathrm{r}=0.763)$. EELV was not correlated to the overly aerated lung volume (table 1). However, at PEEP $>16 \mathrm{~cm} \mathrm{H}_{2} \mathrm{O}, \mathrm{VD}_{\text {alv }} / \mathrm{VT}_{\text {alv }}$ was correlated to the overly aerated lung volumes $(\mathrm{r}=$ 0.558 ) but not to venous admixture.

Compared to PEEP $20 \mathrm{~cm} \mathrm{H}_{2} \mathrm{O}, \mathrm{PaCO}_{2}$ decreased, $\mathrm{pH}$ increased, and plateau airway pressure decreased by each decrement from PEEP 16 to $8 \mathrm{~cm} \mathrm{H}_{2} \mathrm{O}$ (table 2). Simultaneously, cardiac output increased at PEEP 12 and $8 \mathrm{~cm}$
$\mathrm{H}_{2} \mathrm{O}$, and mean arterial pressure increased at each PEEP decrement from 16 to $4 \mathrm{~cm} \mathrm{H}_{2} \mathrm{O}$ (table 3). However, global oxygen delivery and mixed venous oxygen saturation were improved at PEEP 16 and $12 \mathrm{~cm} \mathrm{H}_{2} \mathrm{O}$ (table 3).

\section{Discussion}

The results of this study suggest that in this surfactantdepleted model, volumetric capnography may be a useful method to titrate the optimal PEEP. The PEEP levels producing the lowest $\mathrm{VD}_{\text {alv }} / \mathrm{VT}_{\text {alv }}$ and $\mathrm{S}_{\mathrm{III}}$ are the best predictors as the lung morphology analysis indicated that the maximum amount of effectively ventilated alveoli correlated best to these PEEP levels.

ARDS significantly influences volumetric capnography. After stabilizing the ARDS model, $\mathrm{VD}_{\text {phy }} / \mathrm{VT}$ in- 
Fig. 3. Changes in 4 different aerated lung regions in the ARDS model and during the decremental PEEP trial. * $\mathrm{p}<0.05$ vs. ARDS; ${ }^{* *}$ p $<0.05$ vs. PEEP20 (PEEP $20 \mathrm{~cm}$ $\left.\mathrm{H}_{2} \mathrm{O}\right)$. Data are expressed as means \pm SD. $\mathrm{V}_{\text {normally aerated }}=$ Normally aerated lung volume; $\mathrm{V}_{\text {poorly aerated }}=$ poorly aerated lung volume; $\mathrm{V}_{\text {nonaerated }}=$ nonaerated lung volume; $\mathrm{V}_{\text {overly aerated }}=$ overly aerated lung volume.

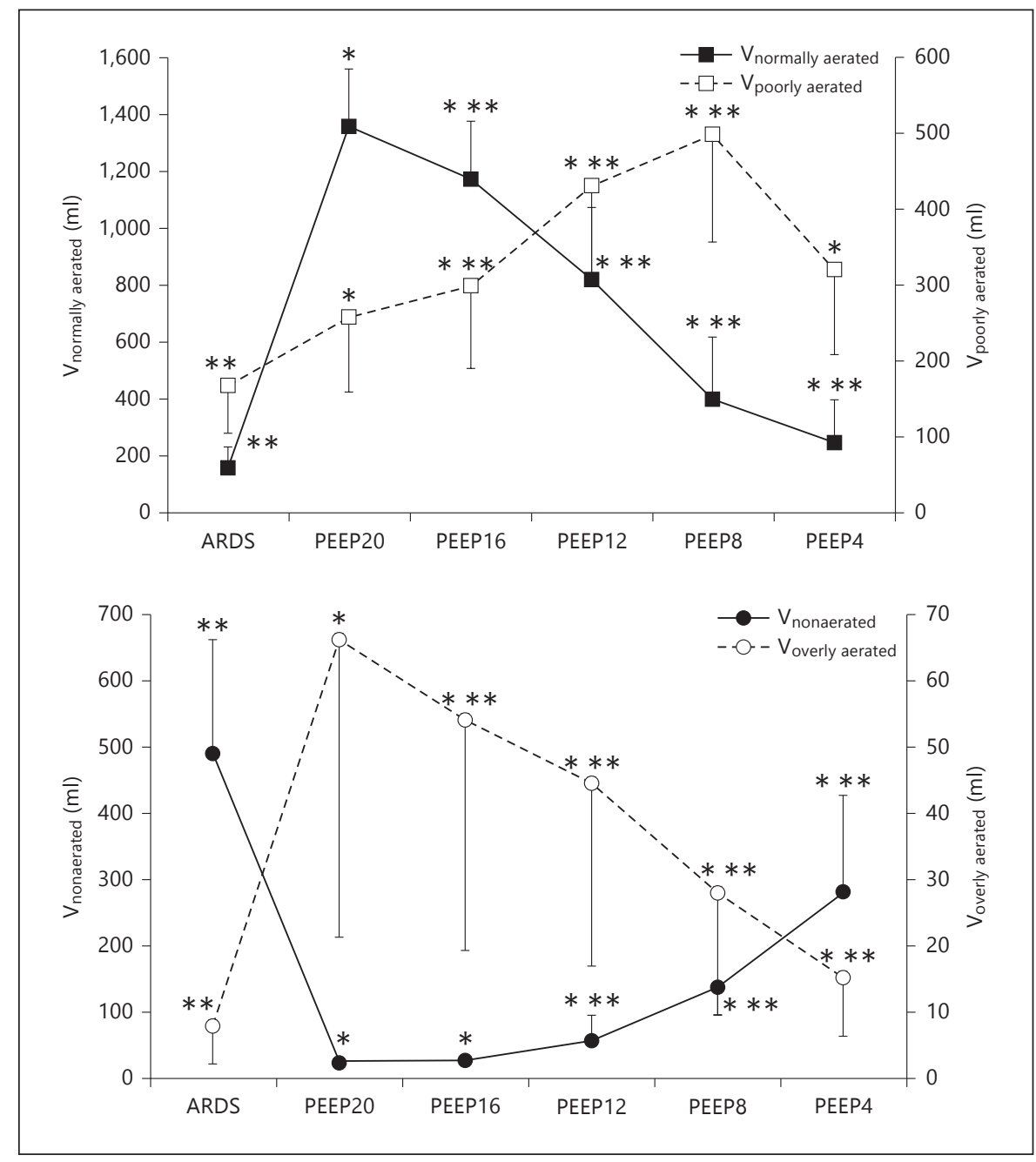

creased significantly, mainly because of the increment in $\mathrm{VD}_{\mathrm{alv}} / \mathrm{VT}_{\text {alv }}$. As $\mathrm{VD}_{\text {phy }} / \mathrm{VT}$ was calculated according to the Enghoff modification of the Bohr equation, venous admixture had a significant influence on the computation of $\mathrm{VD}_{\text {alv }}$ [18], as evidenced by the significant linear relationship between $\mathrm{VD}_{\mathrm{alv}} / \mathrm{VT}_{\mathrm{alv}}$ and venous admixture. This type of $\mathrm{VD}_{\mathrm{alv}}$, which is more suitably considered 'shunt dead space' [19], had nothing to do with real $\mathrm{VD}_{\mathrm{alv}}$. Our data demonstrated that overly aerated lung volumes, most likely to be $\mathrm{VD}_{\mathrm{alv}}$, were only $8 \pm 2 \mathrm{ml}$ during ARDS.

Our data showed that PEEP had bimodal effects on $\mathrm{VD}_{\text {phy }} / \mathrm{VT}$ and $\mathrm{VD}_{\text {alv }} / \mathrm{VT}_{\text {alv }}$. However, they did not change by the same pattern: $\mathrm{VD}_{\text {alv }} / \mathrm{VT}_{\mathrm{alv}}$ reached the minimum at a PEEP of $16 \mathrm{~cm} \mathrm{H}_{2} \mathrm{O}$ while the lowest $\mathrm{VD}_{\text {phy }} / \mathrm{VT}$ was at a PEEP of $12 \mathrm{~cm} \mathrm{H}_{2} \mathrm{O}$. Because $\mathrm{VD}_{\text {alv }} / \mathrm{VT}_{\text {alv }}$ was highly correlated with nonaerated lung regions and venous admix-

Titration of PEEP by Volumetric Capnography ture, it was sufficiently sensitive to detect lung collapse. Since the lung started collapsing and venous admixture increased at a PEEP of $12 \mathrm{~cm} \mathrm{H}_{2} \mathrm{O}, \mathrm{VD}_{\text {alv }} / \mathrm{VT}_{\mathrm{alv}}$ increased again. In contrast, at PEEP $>16 \mathrm{~cm} \mathrm{H}_{2} \mathrm{O}, \mathrm{VD}_{\text {alv }} / \mathrm{VT}_{\text {alv }}$ was not correlated with increased venous admixture but rather with an overly aerated lung. These results are in line with previous studies, which demonstrated that increments in $\mathrm{VD}_{\mathrm{alv}} / \mathrm{VT}_{\mathrm{alv}}$ at high PEEP was caused by high ventilation/perfusion regions in oleic acid-induced lung injury $[9,10]$. Hence, PEEP at the lowest of $\mathrm{VD}_{\mathrm{alv}} / \mathrm{VT}_{\mathrm{alv}}$ corresponded to the best compromise between alveolar recruitment and overinflation.

In contrast to $\mathrm{VD}_{\text {alv }} / \mathrm{VT}_{\text {alv }}, \mathrm{VD}_{\text {phy }} / \mathrm{VT}$ was obviously affected by $\mathrm{VD}_{\text {anat }} / \mathrm{VT}$. A previous study showed that an increase in $\mathrm{VD}_{\text {phy }}$ caused by PEEP was prominently attributed to changes in $\mathrm{VD}_{\text {anat }}$, which was possibly due to airway distension resulting from an increase in EELV [9]. 
Fig. 4. Changes in volumetric capnography variables at baseline, in the ARDS model and during the decremental PEEP trial. * $\mathrm{p}<0.05$ vs. ARDS; ${ }^{* *} \mathrm{p}<0.05$ vs. PEEP20 (PEEP $20 \mathrm{~cm} \mathrm{H}_{2} \mathrm{O}$ ). Data are expressed as means \pm SD.

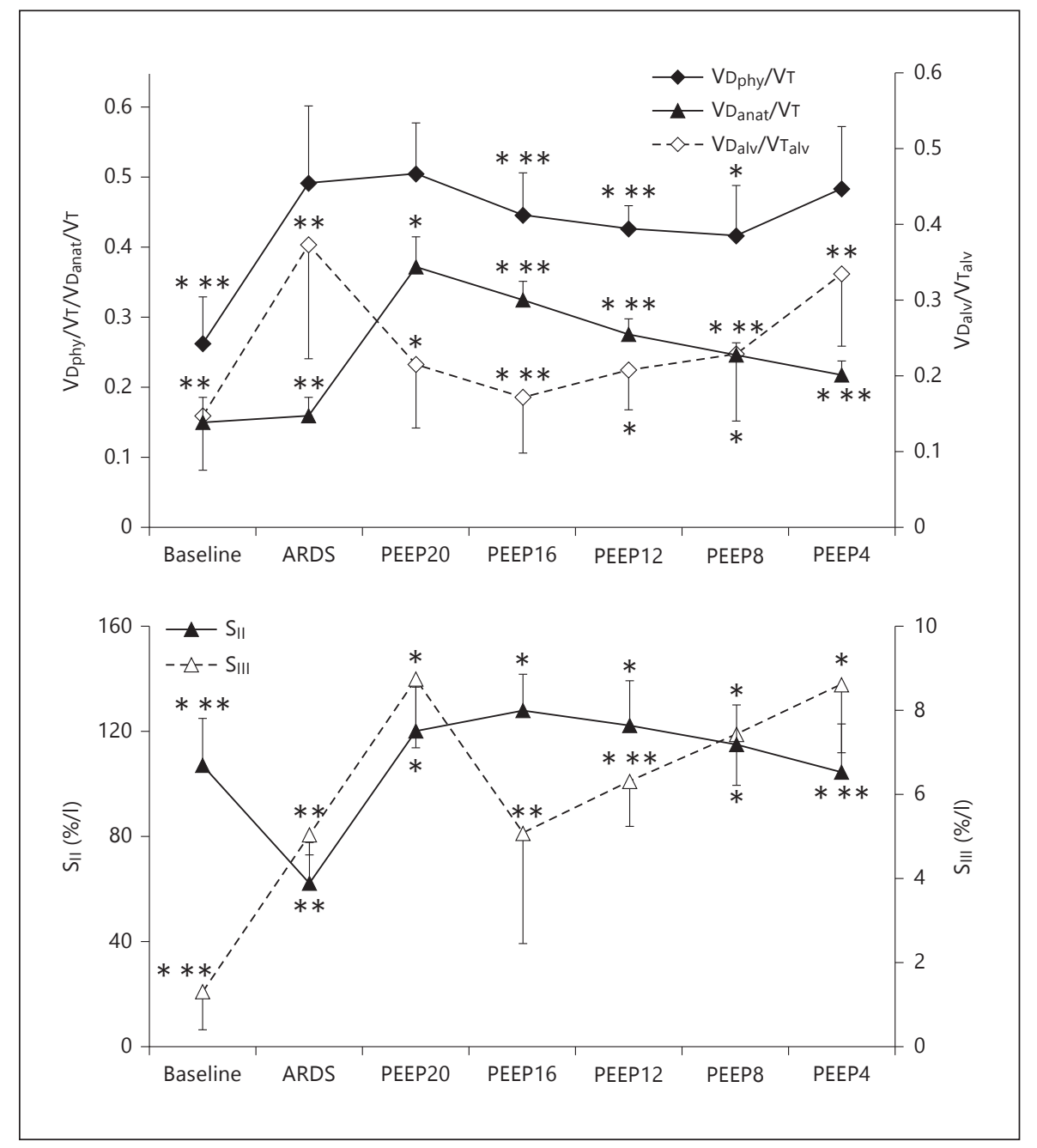

The decline in $\mathrm{VD}_{\text {anat }}$ counteracted the increment in $\mathrm{VD}_{\mathrm{alv}}$, which caused the minimum $\mathrm{VD}_{\text {phy }} / \mathrm{VT}$ at a PEEP of $12 \mathrm{~cm} \mathrm{H}_{2} \mathrm{O}$. However, lung tissue had already started to collapse at this PEEP level as evidenced by the CT analysis. Hence, $\mathrm{VD}_{\text {alv }} / \mathrm{VT}_{\text {alv }}$ better predicts optimal PEEP than $\mathrm{VD}_{\text {phy }} / \mathrm{VT}$. Our results correspond to those of a previous study conducted by Tusman et al. [8], who showed that $\mathrm{VD}_{\text {alv }} / \mathrm{VT}_{\text {alv }}$ had a higher sensitivity and specificity than $\mathrm{VD}_{\text {phy }} / \mathrm{VT}$ for detecting lung collapse.

In addition to $\mathrm{VD}_{\mathrm{alv}} / \mathrm{VT}_{\mathrm{alv}}$, $\mathrm{S}_{\mathrm{III}}$ was helpful in determining the optimal PEEP. Our data show that during the decremental PEEP trial, $\mathrm{S}_{\text {III }}$ had a similar predictive value as $\mathrm{VD}_{\mathrm{alv}} / \mathrm{VT}_{\mathrm{alv}}$. The lowest $\mathrm{S}_{\mathrm{III}}$ corresponded to the best lung function, indicated by a balance between lung recruitment and overinflation. Although the genesis of $\mathrm{S}_{\text {III }}$ is controversial, spatial distribution of ventilation and perfusion together with different time constants of the expired gas volume contribute to its origin [20]. $\mathrm{S}_{\mathrm{III}}$ is a useful variable for detecting alveolar recruitment in patients undergoing thoracic surgery when PEEP is titrated according to the maximum Crs [7]. After lavage-induced lung injury, the lowest $\mathrm{S}_{\text {III }}$ was associated with the minimum ventilation/perfusion dispersion [21]. Hence, $\mathrm{S}_{\text {III }}$ may be a useful variable for detecting changes in lung function. Moreover, as $\mathrm{S}_{\mathrm{III}}$ can be continuously monitored without measuring arterial blood gases, in difference to $\mathrm{VD}_{\text {alv }} / \mathrm{VT}_{\text {alv }}, \mathrm{S}_{\mathrm{III}}$ is superior to $\mathrm{VD}_{\text {alv }} / \mathrm{VT}_{\text {alv }}$ in determining the optimal PEEP due to its noninvasivity.

Our findings show that changes in EELV are not a sensitive variable to detect lung collapse during a decremental PEEP trial. These findings partially differ from those by Rylander et al. [22] and Lambermont et al. [23], who demonstrated that EELV was a sensitive indicator 
Table 1. Pearson correlations between EELV, volumetric capnography variables and different aerated lung regions/intrapulmonary shunt $\left({ }^{*} \mathrm{p}<0.05\right)$

\begin{tabular}{lccccc}
\hline & $\mathrm{V}_{\text {non }}, \mathrm{ml}$ & $\mathrm{V}_{\text {poorly }}, \mathrm{ml}$ & $\mathrm{V}_{\text {normally }}, \mathrm{ml}$ & $\mathrm{V}_{\text {overly }}$, ml & Venous admixture \\
\hline $\mathrm{EELV}, \mathrm{ml}$ & $-0.715^{*}$ & 0.079 & $0.918^{*}$ & $0.592^{*}$ & $-0.657^{*}$ \\
$\mathrm{VD}_{\mathrm{alv}} / \mathrm{VT}_{\text {alv }}$ & $0.681^{*}$ & -0.232 & $-0.512^{*}$ & -0.202 & $0.763^{*}$ \\
$\mathrm{~S}_{\mathrm{II}}, \% / \mathrm{l}$ & $-0.789^{*}$ & $0.460^{*}$ & $0.512^{*}$ & 0.264 & $-0.591^{*}$ \\
$\mathrm{~S}_{\mathrm{III}}, \% / \mathrm{l}$ & -0.165 & 0.112 & 0.034 & -0.016 & 0.156 \\
\hline
\end{tabular}

Table 2. Gas exchange, respiratory mechanics and volumetric capnography variables

\begin{tabular}{|c|c|c|c|c|c|c|c|}
\hline & $\begin{array}{l}\text { Baseline } \\
\text { ZEEP }\end{array}$ & $\begin{array}{l}\text { ARDS } \\
\text { ZEEP }\end{array}$ & $\begin{array}{l}\text { PEEP } \\
20 \mathrm{~cm} \mathrm{H}_{2} \mathrm{O}\end{array}$ & $\begin{array}{l}\text { PEEP } \\
16 \mathrm{~cm} \mathrm{H}_{2} \mathrm{O}\end{array}$ & $\begin{array}{l}\text { PEEP } \\
12 \mathrm{~cm} \mathrm{H}_{2} \mathrm{O}\end{array}$ & $\begin{array}{l}\text { PEEP } \\
8 \mathrm{~cm} \mathrm{H}_{2} \mathrm{O}\end{array}$ & $\begin{array}{l}\text { PEEP } \\
4 \mathrm{~cm} \mathrm{H}_{2} \mathrm{O}\end{array}$ \\
\hline $\mathrm{PaCO}_{2}, \mathrm{~mm} \mathrm{Hg}$ & $37.7 \pm 4.4^{*, * *}$ & $43.4 \pm 7.0^{* *}$ & $48.3 \pm 9.8^{*}$ & $45.2 \pm 7.2$ & $45.8 \pm 6.9$ & $44.3 \pm 9.5$ & $50.4 \pm 14.8$ \\
\hline $\mathrm{PvCO}_{2}, \mathrm{~mm} \mathrm{Hg}$ & $46.1 \pm 6.6^{*, * *}$ & $52.6 \pm 10.3^{* *}$ & $62.7 \pm 13.6^{*}$ & $60.4 \pm 10.9^{*}$ & $55.2 \pm 7.6^{* *}$ & $54.5 \pm 10.0$ & $59.0 \pm 16.0$ \\
\hline $\mathrm{pH}$ & $7.47 \pm 0.03^{*, * *}$ & $7.42 \pm 0.06^{* *}$ & $7.34 \pm 0.08^{*}$ & $7.37 \pm 0.06^{*, * *}$ & $7.39 \pm 0.05^{* *}$ & $7.40 \pm 0.06^{* *}$ & $7.37 \pm 0.08$ \\
\hline $\mathrm{P}_{\text {plat }}, \mathrm{cm} \mathrm{H}_{2} \mathrm{O}$ & $12.6 \pm 2.4^{*, * *}$ & $25.4 \pm 4.5^{* *}$ & $30.8 \pm 1.8^{*}$ & $24.8 \pm 1.8^{* *}$ & $20.6 \pm 2.0^{*, * *}$ & $20.4 \pm 3.5^{*, * *}$ & $23.2 \pm 4.0$ \\
\hline $\mathrm{P}_{\text {mean }}, \mathrm{cm} \mathrm{H}_{2} \mathrm{O}$ & $5.5 \pm 0.8^{*, * *}$ & $9.6 \pm 0.9^{* *}$ & $25.3 \pm 3.5^{*}$ & $20.4 \pm 2.1^{*, * *}$ & $15.6 \pm 0.5^{*, * *}$ & $12.6 \pm 0.8^{*, * *}$ & $10.5 \pm 1.2^{* *}$ \\
\hline $\mathrm{VD}_{\text {phy }}, \mathrm{ml}$ & $93 \pm 31^{*}$ & $170 \pm 52^{* *}$ & $111 \pm 21^{*}$ & $100 \pm 16^{*, * *}$ & $94 \pm 12^{*, * *}$ & $95 \pm 16^{*}$ & $108 \pm 19^{*}$ \\
\hline $\mathrm{VD}_{\mathrm{alv}}, \mathrm{ml}$ & $48 \pm 20^{*, * *}$ & $120 \pm 48^{* *}$ & $31 \pm 10^{*}$ & $26 \pm 11^{*}$ & $34 \pm 7^{*}$ & $39 \pm 13^{*}$ & $56 \pm 15^{*, * *}$ \\
\hline $\mathrm{VD}_{\text {anat }}, \mathrm{ml}$ & $56 \pm 14^{* *}$ & $55 \pm 11^{* *}$ & $82 \pm 13^{*}$ & $73 \pm 12^{*, * *}$ & $62 \pm 10^{*, * *}$ & $55 \pm 8^{* *}$ & $50 \pm 9^{* *}$ \\
\hline
\end{tabular}

Data are expressed as means $\pm \mathrm{SD} . \mathrm{ZEEP}=$ Zero end-expiratory pressure; $\mathrm{PaCO}_{2}=$ arterial partial pressure of carbon dioxide; $\mathrm{PvCO}=$ mixed venous partial pressure of carbon dioxide; $\mathrm{P}_{\text {plat }}=$ plateau pressure; $\mathrm{P}_{\text {mean }}=$ mean airway pressure. ${ }^{*} \mathrm{p}<0.05 \mathrm{vs}$. ARDS; ${ }^{* *} \mathrm{p}<0.05$ vs. PEEP $20 \mathrm{~cm} \mathrm{H}_{2} \mathrm{O}$.

Table 3. Hemodynamic data

\begin{tabular}{|c|c|c|c|c|c|c|c|}
\hline & $\begin{array}{l}\text { Base } \\
\text { ZEEP }\end{array}$ & $\begin{array}{l}\text { ARDS } \\
\text { ZEEP }\end{array}$ & $\begin{array}{l}\text { PEEP } \\
20 \mathrm{~cm} \mathrm{H}_{2} \mathrm{O}\end{array}$ & $\begin{array}{l}\text { PEEP } \\
16 \mathrm{~cm} \mathrm{H}_{2} \mathrm{O}\end{array}$ & $\begin{array}{l}\text { PEEP } \\
12 \mathrm{~cm} \mathrm{H}_{2} \mathrm{O}\end{array}$ & $\begin{array}{l}\text { PEEP } \\
8 \mathrm{~cm} \mathrm{H}_{2} \mathrm{O}\end{array}$ & $\begin{array}{l}\text { PEEP } \\
4 \mathrm{~cm} \mathrm{H}_{2} \mathrm{O}\end{array}$ \\
\hline $\mathrm{CO}, 1 / \mathrm{min}$ & $6.3 \pm 0.7^{*, * *}$ & $5.3 \pm 0.7$ & $5.0 \pm 1.1$ & $5.6 \pm 1.3$ & $5.8 \pm 1.5^{* *}$ & $5.7 \pm 1.3^{* *}$ & $5.4 \pm 1.2$ \\
\hline MAP, mm Hg & $117 \pm 17^{* *}$ & $110 \pm 17^{* *}$ & $93 \pm 5.0^{*}$ & $96 \pm 12^{*}$ & $105 \pm 12^{* *}$ & $112 \pm 13^{* *}$ & $127 \pm 21^{*, * *}$ \\
\hline mPAP, mm Hg & $15.6 \pm 3.7^{*, * *}$ & $25.5 \pm 8.2$ & $25.3 \pm 3.4$ & $24.4 \pm 3.6$ & $24.4 \pm 3.6$ & $27.6 \pm 6.4$ & $33.6 \pm 9.2^{*, * *}$ \\
\hline $\mathrm{S}_{\mathrm{v}} \mathrm{O}_{2}, \%$ & $81.1 \pm 4.2^{*, * *}$ & $62.6 \pm 10.7$ & $70.1 \pm 4.3$ & $74.7 \pm 3.1^{*, * *}$ & $76.7 \pm 3.1^{*, * *}$ & $74.6 \pm 7.1^{*}$ & $66.2 \pm 13.9$ \\
\hline
\end{tabular}

Data are expressed as means $\pm \mathrm{SD} . \mathrm{ZEEP}=$ Zero end-expiratory pressure; $\mathrm{MAP}=$ mean systemic arterial pressure; $\mathrm{mPAP}=\mathrm{mean}$ pulmonary artery pressure; $\mathrm{CO}=$ cardiac output; $\mathrm{S}_{\mathrm{v}} \mathrm{O}_{2}=$ mixed venous oxygen saturation; $\mathrm{DO}_{2}=$ oxygen delivery. ${ }^{*} \mathrm{p}<0.05$ vs. ARDS; ** $\mathrm{p}<0.05$ vs. PEEP $20 \mathrm{~cm} \mathrm{H}_{2} \mathrm{O}$.

of PEEP-induced lung recruitment in oleic acid-induced lung injury. The most likely explanation for the divergent results is that we titrated PEEP after full lung recruitment, whereas Rylander et al. [22] and Lambermont et al. [23] did not perform an RM. Luecke et al. [24] observed that the inflation and recruitment curves were nearly identical for the inflation limb of the pressure- volume curve, while there was a marked difference between the deflation and derecruitment curves on the deflation limb of the pressure-volume curve in both oleic acid and lavage-induced lung injury. Hence, without an RM, the increment change in EELV induced by PEEP is highly associated with lung recruitment, whereas after full lung recruitment, the decrement change in EELV 
caused by a reduction in PEEP from high levels reflects the deflation of ventilated lung units and the alleviation of overly aerated lung regions, but not alveolar derecruitment.

Concerns have been voiced about the potential risk of hemodynamic impairment during the open lung strategy. Our data showed that PEEP had significant impact on mean arterial pressure and cardiac output, especially at PEEP $20 \mathrm{~cm} \mathrm{H}_{2} \mathrm{O}$. However, at the PEEP level of the lowest $\mathrm{VD}_{\mathrm{alv}} / \mathrm{VT}_{\mathrm{alv}}$ or $\mathrm{S}_{\mathrm{III}}$, not only the hemodynamics but also global oxygen delivery and mixed venous oxygen saturation were significantly increased, implying the improvement in global oxygen delivery and consumption. Accordingly, the PEEP level titrated by volumetric capnography will provide sufficient lung protection and oxygen metabolism.

\section{Limitations}

There are some limitations to this study. First, the saline lavage model used in this study induces severe surfactant depletion and is characterized by high recruitability. However, lung recruitability is variable in patients with acute lung injury/ARDS [25]. Therefore, these results should be interpreted cautiously when applied to these patients. Second, time intervals of $10 \mathrm{~min}$ at each PEEP may not have allowed stable measurements, particularly for the $\mathrm{CO}_{2}$ exchange. However, a recent study showed that the elimination of $\mathrm{CO}_{2}$ reached a new stable period within $5 \mathrm{~min}$ of a PEEP change [26].

\section{Conclusions}

In lavage-induced lung injury, PEEP at the lowest $\mathrm{VD}_{\mathrm{alv}} / \mathrm{VT}_{\mathrm{alv}}$ and $\mathrm{S}_{\mathrm{III}}$ corresponded to a balance between alveolar recruitment and overinflation. Hence, volumetric capnography may be a valuable bedside approach to determine the optimal PEEP.

\section{Acknowledgments}

The study was funded by a project of the National Key Clinical Specialty Construction (2100299) and the Jiangsu Key Medical Discipline (889-KJXW11.3).

\section{References}

1 Gattinoni L, Caironi P, Carlesso E: How to ventilate patients with acute lung injury and acute respiratory distress syndrome. Curr Opin Crit Care 2005; 11:69-76.

$>2$ Putensen C, Theuerkauf N, Zinserling J, Wrigge H, Pelosi P: Meta-analysis: ventilation strategies and outcomes of the acute respiratory distress syndrome and acute lung injury. Ann Intern Med 2009;151:566576.

>3 Rouby J-J, Ferrari F, Bouhemad B, Lu Q: Positive end-expiratory pressure in acute respiratory distress syndrome: should the 'open lung strategy' be replaced by a 'protective lung strategy’? Crit Care 2007;11:180.

4 Brochard L: New goals for positive end-expiratory pressure in acute respiratory distress syndrome: a paradigm shift or the end of an area of uncertainty? Am J Respir Crit Care Med 2010;181:528-530.

$\checkmark 5$ Nuckton TJ, Alonso JA, Kallet RH, Daniel BM, Pittet JF, Eisner MD, Matthay MA: Pulmonary dead-space fraction as a risk factor for death in the acute respiratory distress syndrome. N Engl J Med 2002;346:12811286.

6 Raurich JM, Vilar M, Colomar A, Ibanez J, Ayestaran I, Perez-Barcena J, Llompart-Pou JA: Prognostic value of the pulmonary dead-space fraction during the early and in- termediate phases of acute respiratory distress syndrome. Respir Care 2010;55:282287.

-7 Tusman G, Bohm SH, Suarez-Sipmann F, Turchetto E: Alveolar recruitment improves ventilatory efficiency of the lungs during anesthesia. Can J Anaesth 2004;51: 723-727.

-8 Tusman G, Suarez-Sipmann F, Bohm SH, Pech T, Reissmann H, Meschino G, Scandurra A, Hedenstierna G: Monitoring dead space during recruitment and PEEP titration in an experimental model. Intensive Care Med 2006;32:1863-1871.

$>9$ Dueck R, Wagner PD, West JB: Effects of positive end-expiratory pressure on gas exchange in dogs with normal and edematous lungs. Anesthesiology 1977;47:359-366.

10 Coffey RL, Albert RK, Robertson HT: Mechanisms of physiological dead space response to PEEP after acute oleic acid lung injury. J Appl Physiol 1983;55:1550-1557.

11 Breen PH, Mazumdar B: How does positive end-expiratory pressure decrease $\mathrm{CO}_{2}$ elimination from the lung? Respir Physiol 1996; 103:233-242.

12 Suter PM, Fairley HB, Isenberg MD: Optimum end-expiratory airway pressure in patients with acute pulmonary failure. N Engl J Med 1975;292:284-289.
-13 Fengmei G, Jin C, Songqiao L, Congshan Y, Yi Y: Dead space fraction changes during PEEP titration following lung recruitment in patients with ARDS. Respir Care 2012;57: 1578-1585.

14 Borges JB, Okamoto VN, Matos GFJ, Caramez MPR, Arantes PR, Barros F, Souza CE Victorino JA, Kacmarek RM, Barbas CSV, Carvalho CRR, Amato MBP: Reversibility of lung collapse and hypoxemia in early acute respiratory distress syndrome. Am J Respir Crit Care Med 2006;174:268-278.

15 Olegård C, Söndergaard S, Houltz E, Lundin S, Stenqvist O: Estimation of functional residual capacity at the bedside using standard monitoring equipment: a modified nitrogen washout/washin technique requiring a small change of the inspired oxygen fraction. Anesth Analg 2005;101:206-212.

16 Puybasset L, Cluzel P, Gusman P, Grenier P, Preteux F, Rouby JJ: Regional distribution of gas and tissue in acute respiratory distress syndrome. I. Consequences for lung morphology. CT Scan ARDS Study Group. Intensive Care Med 2000;26:857-869.

17 Gattinoni L, Caironi P, Pelosi P, Goodman LR: What has computed tomography taught us about the acute respiratory distress syndrome? Am J Respir Crit Care Med 2001;164: 1701-1711. 
18 Niklason L, Eckerstrom J, Jonson B: The influence of venous admixture on alveolar dead space and carbon dioxide exchange in acute respiratory distress syndrome: computer modelling. Crit Care 2008;12:R53.

19 Hedenstierna G, Sandhagen B: Assessing dead space. A meaningful variable? Minerva Anestesiol 2006;72:521-528.

-20 Suarez Sipmann F, Böhm SH, Tusman G: Different approaches to the analysis of volumetric capnography; in Vincent J-L (ed): Yearbook of Intensive Care and Emergency Medicine. Berlin, Springer, 2009, pp 413-423.

-21 Tusman G, Suarez-Sipmann F, Bohm SH, Borges JB, Hedenstierna G: Capnography reflects ventilation/perfusion distribution in a model of acute lung injury. Acta Anaesthesiol Scand 2011;55:597-606.
22 Rylander C, Högman M, Perchiazzi G, Magnusson A, Hedenstierna G: Functional residual capacity and respiratory mechanics as indicators of aeration and collapse in experimental lung injury. Anesth Analg 2004;98: 782-789.

23 Lambermont B, Ghuysen A, Janssen N, Morimont P, Hartstein G, Gerard P, D'Orio $\mathrm{V}$ : Comparison of functional residual capacity and static compliance of the respiratory system during a positive end-expiratory pressure (PEEP) ramp procedure in an experimental model of acute respiratory distress syndrome. Crit Care 2008;12:R91.
24 Luecke T, Meinhardt JP, Herrmann P, Weiss A, Quintel M, Pelosi P: Oleic acid vs saline solution lung lavage-induced acute lung injury: effects on lung morphology, pressurevolume relationships, and response to positive end-expiratory pressure. Chest 2006;130: 392-401.

25 Gattinoni L, Caironi P, Cressoni M, Chiumello D, Ranieri VM, Quintel M, Russo S, Patroniti N, Cornejo R, Bugedo G: Lung recruitment in patients with the acute respiratory distress syndrome. N Engl J Med 2006;354: 1775-1786.

26 Tusman G, Bohm SH, Suarez-Sipmann F, Scandurra A, Hedenstierna G: Lung recruitment and positive end-expiratory pressure have different effects on $\mathrm{CO}_{2}$ elimination in healthy and sick lungs. Anesth Analg 2010; 111:968-977. 